\title{
Investigation of Epstein-Barr Virus DNA in Formalin-Fixed and Paraffin- Embedded Breast Cancer Tissues
}

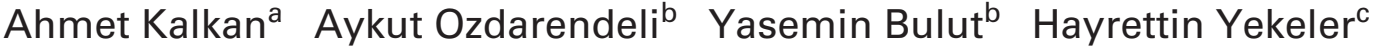 \\ Bengu Cobanogluc ${ }^{c}$ Mehmet Z. Doymaz ${ }^{d}$ \\ Departments of ${ }^{\mathrm{a}}$ Infectious Diseases, ${ }^{\mathrm{b}}$ Microbiology and ${ }^{\mathrm{c}}$ Pathology, Firat University Medical School, Elazig, Turkey; \\ ${ }^{\mathrm{d} C l i n i c a l}$ Microbiology Laboratory, Beth Israel Medical Center, New York, N.Y., USA
}

\section{Key Words}

Epstein-Barr virus $\cdot$ Breast cancer $\cdot$ Polymerase chain reaction

\begin{abstract}
Objective: To investigate etiological role of Epstein-Barr virus (EBV) DNA in breast cancer. Materials and Methods: The presence of EBV DNA in 57 breast cancer tissues was investigated with a sensitive PCR assay. The breast cancer tissues were from invasive ductular $(n=28)$, lobular $(n=20)$ and other miscellaneous carcinomas $(n=9)$. Tissues from normal breasts and patients with various benign breast diseases $(n=55)$ : fibrocystic disease $(n=$ $34)$, fibroadenoma ( $n=16)$, hyperplasia, and granulomatous mastitis $(\mathrm{n}=5)$, were used as control samples. $\boldsymbol{R} \boldsymbol{e}$ sults: EBV DNA was detected in $13(23 \%)$ cancerous tissues ( 7 ductular, 4 lobular, 2 other carcinoma) and 19 $(35 \%)$ in the control tissues. The difference between EBV presence in malignant and benign tissues was not statistically significant $(p>0.05)$. Conclusion: The presence of EBV DNA was detected almost equally in both breast cancer and normal tissues, which indicates no etiological role for EBV in breast cancer. We suggest further etiological studies.
\end{abstract}

\section{Introduction}

Most human infections with Epstein-Barr virus (EBV) occur early in life and over $90 \%$ of the population carry antibodies specific for this ubiquitous human herpes virus $[1,2]$. It has been demonstrated conclusively that EBV establishes a latent infection in the lymphocytes of the host [2]. Investigators have attempted to demonstrate the causative relationship between EBV and various human tumors [2-4], but direct causative relationship has proven to be difficult to establish [2,4].

Epidemiological, serological and in recent years, molecular data have been used to show the linkage between EBV and various human tumors [5, 6]. Based on published data, it may not be an unreasonable conclusion to suggest that unless there is another cofactor present, EBV by itself, rarely, causes malignancy in humans [5, 7]. However, in cases of Burkitt's and Hodgkin's lymphomas, and B cell lymphoma in immunocompromised subjects and nasopharyngeal carcinoma, strong associations have been established between EBV and the malignancies $[2,8]$. Extensive body of literature on the possible role of EBV in gastric carcinoma, $\mathrm{T}$ cell lymphoma, and lymphoepithelioma in the lungs and in the thymus and leiomyosarcoma in immunocompromised patients $[9,10]$ exists.

\section{KARGER}

Fax +4161306 1234 E-Mail karger@karger.ch www.karger.com 
The presence of EBV genetic material in breast cancer tissues has been reported [11]. However, conclusive evidence has not been demonstrated on the etiological role of EBV in breast cancer [12-14]. What is known is that EBV is present in subgroups of breast cancer tissues. The frequency of the breast cancer subpopulations carrying EBV genome seems to be influenced by various factors such as the methodologies, geographical regions and the ethnic background of the subjects [15-17]. In the present study, we investigated EBV DNA in the breast cancer tissues collected from Eastern Anatolian region of Turkey.

\section{Subjects and Methods}

\section{Tissues}

A total of 57 tissue specimens submitted to Pathology Laboratories of Firat University Medical Center and Elazig State Hospital, Elazig, Turkey for diagnosis of various breast diseases were included in the study. Twenty-eight invasive ductular carcinoma, 20 invasive lobular carcinoma and 9 various malignant lesion samples comprised the test group. A total of 55 samples from normal and benign lesions of the breast served as the negative control: 34 fibrocystic disease samples, 16 fibroadenomatous tissues, and 5 various benign lesion/normal breast samples. The tissue samples were collected between 1996 and 2004 and kept at departmental archives. The biopsy specimens were collected, fixed with $10 \%$ buffered formalin and embedded in paraffin using standard techniques.

\section{Extraction of DNA and PCR}

DNA was isolated from 5 sections at $10 \mu \mathrm{m}$ thickness obtained from each specimen and from EBV-transformed lymphoblast cells, BL1514, as previously described [18]. Briefly, the tissues were digested in $500 \mu$ l digestion buffer $(10 \mathrm{~m} M$ Tris, $\mathrm{pH}$ 7.4, $100 \mathrm{mM}$ $\mathrm{NaCl}, 25 \mathrm{~m} M$ EDTA, $0.5 \%$ SDS and $40 \mathrm{~m} M$ DTT containing proteinase $\mathrm{K}$ at $200 \mathrm{mg} / \mathrm{ml}$ concentration) at $37^{\circ} \mathrm{C}$ for $16 \mathrm{~h}$. The DNA was extracted with equal volumes of phenol:choloroform:isoamyl alcohol (25:24:1) and choloroform:isoamyl alcohol (24:1). The aqueous phase was transferred to new vials to which $1 / 4$ volume of $8 M$ ammonium acetate, $\mathrm{pH} 4.8$, was added. DNA was precipitated with equal volume isopropanol and washed in $70 \%$ cold ethanol, resuspended in $20 \mu \mathrm{l}$ sterile $\mathrm{dH}_{2} \mathrm{O}$ and stored at $-20^{\circ} \mathrm{C}$ until used in the assay $[18,19]$. As a contamination control, a vial containing $50 \mu \mathrm{l}$ sterile $\mathrm{dH}_{2} \mathrm{O}$ was included in the DNA extraction protocol. Another negative control containing $10 \mu \mathrm{l}$ sterile $\mathrm{dH}_{2} \mathrm{O}$ as a template was added in each assay. For positive control, EBV-transformed lymphoblast cell line BL1514 (NCI-BL1514, CRL-5952, American Type Culture Collection, Manassas, Va., USA) DNA was used as a template in each run.

Each DNA sample was first tested for suitability for PCR analysis by amplification of beta globulin gene sequences. Only positive samples were further analyzed for amplification of EBV DNA sequences. For PCR reaction, $10 \mu \mathrm{l}$ isolated DNA was used as template. PCR reactions were carried out in a $50-\mu 1$ volume. The primers (gp1, 5'-GGC TGG TGT CAC ATC TGT TA-3' and gp2, 5'CCT TAG GAG GAA CAA GTC CC-3') were specific for gp220 gene of EBV and amplified a 239-base pair fragment. These prim-

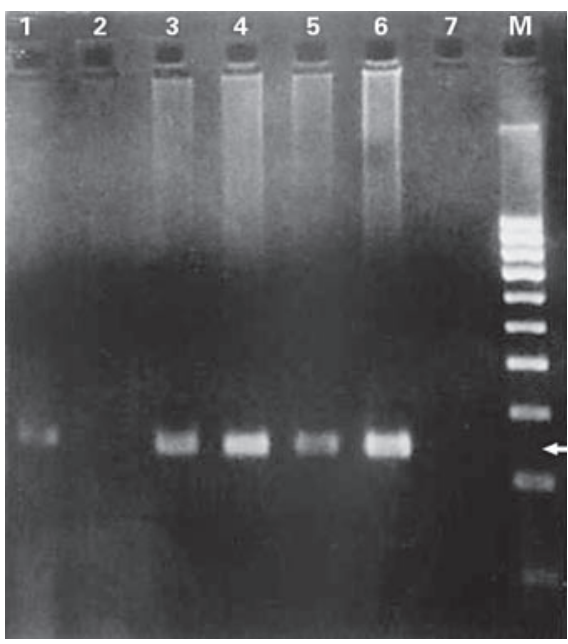

Fig. 1. PCR products were analyzed on a $2 \%$ agarose gel electrophoresis. The DNA ladder (lane M) and a 259-bp marker (lane 1) were used in orienting 239-bp EBV-specific DNA bands (lanes 3, 4 and 5) from test samples. Contamination control and negative control (lanes 2 and 7, respectively) and positive control (lane 6) were included in each assay.

ers were used to detect both EBV-1 and EBV-2 sequences [20]. The forward primer gp1 and the probe primer (5'-GGT GGA GGG GCT GAG TGT CTC TGG GTT TGA ACT GGG-3') were used for confirming the fidelity of amplification produced 120-bp products. The PCR was continued for 45 cycles and each cycle consisted of denaturation $\left(94^{\circ} \mathrm{C}\right.$ for $\left.60 \mathrm{~s}\right)$, annealing $\left(60^{\circ} \mathrm{C}\right.$ for $\left.60 \mathrm{~s}\right)$ and extension $\left(72^{\circ} \mathrm{C}\right.$ for $\left.60 \mathrm{~s}\right)$ steps. PCR products $(10 \mu \mathrm{l})$ were mixed with $2 \mu 1 \times 6$ gel loading buffer and loaded onto $2 \%$ agarose gel. The gel also contained ethidium bromide $(0.5 \mathrm{mg} / \mathrm{ml})$ and the amplified DNA fragments were visualized with ultraviolet light (fig. 1).

Initially, the sensitivity of PCR was established with plasmid DNA containing PCR-generated EBV amplicon. For this purpose, 239-bp amplicon from PCR in which EBV-transformed human lymphoblast DNA was cloned into pGEM-T vector (Promega Co., Madison, Wisc., USA) as described by the manufacturer. The cell lines were maintained in 10\% fetal bovine serum (Sigma Chemical Co., St. Louis, Mo., USA) containing Dulbecco's Modified Eagle's Medium Nutrient Mixture F-12 (DME/F-12, Sigma). The cellular DNA was extracted with the procedure described above. The resultant plasmid, pEBVGEM, was transformed into Escherichia coli (JM 109) and plasmid DNA was extracted with standard molecular biological protocols [19].

\section{Results}

The subjects ranged in age from 17 and 76 (median age of $43 \pm 13$ ). The age distribution of the subjects and PCR results are presented in table 1 . For the malignant 
lesions, EBV-positive samples were mostly in the age range of 30-49 $\geq 60$ years while for normal/benign samples it was mostly in the age range of 20-39 years. Of the 57 breast carcinoma and 55 benign/normal samples, 13 (23\%) and 19 (35\%) were positive for EBV DNA, respectively. The difference between the two groups was not statistically significant ( $p>0.05$ ). Of the 28 invasive ductular, 20 invasive lobular and 9 various malignant lesions, $7(25 \%), 4(30 \%)$, and $2(22 \%)$ were positive for EBV DNA, respectively. The difference between them was not statistically significant $(p>0.05)$. As few as 0.1 copies of EBV per cell in $0.1 \mathrm{mg}$ of DNA was detected.

\section{Discussion}

The 23\% occurrence of positive EBV DNA in the malignant breast cancer samples of this study is within the reported range of $0-51 \%$ of previous studies [17, 18, 21]. More importantly, 35\% of normal/benign tissues was positive for EBV DNA. Equally important, there was not statistically significant difference between the various invasive cancerous tissues as reported by Glaser et al. [22], but not Bonne et al. [15]. Based on our results and that of Glaser [22], we speculate that EBV does not play an etiological role in the carcinogenesis of breast cancer.

The high frequency of EBV presence in benign lesions/ normal breast tissues could be due to high EBV seropositivity in normal populations, which is reported to reach $80 \%$ in metropolitan populations [23]. Unfortunately, we did not investigate the serological status of the subjects included in the study because it was a retrospective analysis of samples in the department. A prospective study on the presence of EBV DNA in blood samples of both patients with various breast carcinomas and control would be useful for understanding the relationship between
Table 1. EBV-specific PCR results of formalin-fixed and paraffinembedded samples from normal breast tissues, from various benign lesions and from patients with breast cancer

\begin{tabular}{|c|c|c|c|c|c|}
\hline \multirow{2}{*}{$\begin{array}{l}\text { Age of the } \\
\text { subjects }\end{array}$} & \multirow{2}{*}{$\begin{array}{l}\text { Speci- } \\
\text { mens }\end{array}$} & \multicolumn{2}{|c|}{ Normal tissue/benign lesions } & \multicolumn{2}{|c|}{ Malignant lesions } \\
\hline & & EBV (+) & EBV (-) & $\overline{\mathrm{EBV}}(+)$ & EBV (-) \\
\hline$>19$ & 2 & 0 & 1 & 0 & 1 \\
\hline $20-29$ & 22 & 10 & 9 & 1 & 2 \\
\hline $30-39$ & 30 & 6 & 12 & 3 & 9 \\
\hline $40-49$ & 28 & 2 & 7 & 4 & 15 \\
\hline $50-59$ & 6 & 1 & 1 & 1 & 3 \\
\hline$\leq 60$ & 24 & - & 6 & 4 & 14 \\
\hline Total & 112 & $19(35 \%)$ & $36(65 \%)$ & $13(23 \%)$ & $44(77 \%)$ \\
\hline
\end{tabular}

EBV seropositivity and EBV DNA-positive tissue samples. Our study did not rule out the possibility that EBV detected in the tissues was originating from the infiltrating lymphocytes.

The regional and ethnic influences on the frequency of EBV positivity in breast cancer tissues are alluded in some reports [4, 24]. However, most studies on the EBV presence in breast cancer tissues are reported from western countries and our report is a contribution to the existing body of data.

\section{Conclusion}

Our results show that a significant subset of breast cancer tissues contains EBV DNA. This conclusion is in agreement with other published results that EBV if causing malignant changes in human breast tissues seems to act so in only a limited subset of the subjects.

\section{References}

1 Cohen JI: Epstein-Barr virus infection. N Engl J Med 2000;343:481-492.

2 Rickinson AB, Kieff E: Epstein-Barr virus; in Knipe DM, Howley PM (eds): 'Field's Virology', ed 2. Philadelphia, Lippincott, Williams \& Wilkins, 2001, pp 2575-2627.

-3 Herrmann K, Niedobitek G: Epstein-Barr virus-associated carcinomas: Facts and fiction. $\mathrm{J}$ Pathol 2003;199:140-145.

4 Thompson MP, Kurzrock R: Epstein-Barr virus and cancer. Clin Cancer Res 2004;10:803821.
5 Crawford DH: Biology and disease associations of Epstein-Barr virus. Philos Trans R Soc Lond 2001;356:461-473.

6 Lopes V, Young LS, Murray PG: Epstein-Barr virus-associated cancers: Aetiology and treatment. Herpes 2003;10:78-82.

7 Griffin B: Epstein-Barr virus (EBV) and human disease: Facts, opinions, and problems. Mutat Res 2000;462:395-405.
8 Henle G, Henle W, Diehl V: Relation of Burkitt's tumor-associated herpes-type virus to infectious mononucleosis. Proc Natl Acad Sci USA 1968;59:94-101.

9 Anagnostopoulos I, Hummel M: Epstein-Barr virus in tumours. Histopathology 1996;29: 297-315.

10 Iezzoni JC, Gaffey MJ, Weiss LM: The role of Epstein-Barr virus in lymphoepithelioma-like carcinomas. Am J Clin Pathol 1995;103:308315. 
11 Labrecque LG, Barnes DM, Fentiman IS, Griffin BE: Epstein-Barr virus in epithelial cell tumors: A breast cancer study. Cancer Res 1995; 55:39-45.

12 Chu JS, Chen CC, Chang KJ: In situ detection of Epstein-Barr virus in breast cancer. Cancer Lett 1998:124:53-57.

13 Hermann K, Niedobitek G: Lack of evidence for an association of Epstein-Barr virus infection with breast carcinoma. Breast Cancer Res 2002;5:R13-17.

14 Touitou R, Bonnet-Duquenoy M, Joab I: Association of Epstein-Barr virus with human mammary carcinoma: Pros and cons. Dis Markers 2001;17:163-165.

15 Bonne M, Guinebretiere J-M, Kremmer E, Grunewald V, Benhamou E, Contesso G, Joab I: Detection of Epstein-Barr virus in invasive breast cancers. J Natl Cancer Inst 1999;91: 1376-1381.
16 Fina F, Romain S, OUafik L, Palmari J, Ben Ayed F, Benharkat S, Bonnier P, Spyratos F, Foekens JA, Rose C, Buisson M, Gerard H, Reymond MO, Seigneurin JM, Martin PM: Frequency and genome load of Epstein-Barr virus in 509 breast cancers from different geographical areas. Br J Cancer 2001;84:783790.

17 Rowe P: EBV associated with aggressive breast cancers. Lancet 1999;354:748.

18 Shimizu H, Burns JC: Extraction of nucleic acids: Sample preparation from paraffin-embedded tissues; in Innis M, Gelfand DH, Sninsky JJ (eds): PCR Strategies. San Diego, Academic Press, 1995, pp 32-38.

19 Sambrook J, Fristsch EF, Maniatis T: Molecular Cloning: A Laboratory Manual. New York, Cold Spring Harbor Laboratory Press, 1989.

20 Telenti A: PCR detection and typing of Epstein-Barr Virus; in Pershing D, Smith TF, Tenover FC, White TJ (eds): Diagnostic Molecular Microbiology: Principles and Applications. Washington, ASM Press, 1993, pp 344349.
1 Lespagnard L, Cochaux P, Larsimont D, Degeyter M, Velu T, Heimann R: Absence of Epstein-Barr virus in medullary carcinoma of the breast as demonstrated by immunophenotyping, in situ hybridization and polymerase chain reaction. Am J Clin Pathol 1995;103:449452.

22 Glaser SL, Hsu JL, Gulley ML: Epstein-Barr virus and breast cancer: State of the evidence for viral carcinogenesis. Cancer Epidemiol Biomarkers Prev 2004;13:688-697.

23 White DO, Fenner FJ: Medical Virology. San Diego, Academic Press, 1994, pp 317-347.

24 Lopategui JR, Gaffey MJ, Weiss LM: Detection of Epstein-Barr viral RNA in sinonasal undifferentiated carcinoma from Western and Asian patients. Am J Surg Pathol 1994;18: 391-398. 